\title{
Az emberi jogok vallása: viták és értelmezések
}

\section{NYIRKOS TAMÁS 1}

A tanulmány az emberi jogok olyan felfogásait vizsgálja, amelyek ezekre egyfajta "hit”, „vallás”, esetleg „világi vallás” tárgyaként tekintenek. Az ilyen megnyilatkozások és a bennük szereplő kifejezések rendkívüli homályossága miatt a vallással vont általános analógia természetesen nem állja meg a helyét, ugyanakkor az emberi jogok elmélete bizonyos vonásaiban valóban rokonságot mutat egyes, általában vallásinak nevezett hagyományokkal, elsősorban a kereszténységgel.

Kulcsszavak: emberi jogok, vallás, világi vallás, kereszténység

\section{The Religion of Human Rights: Debates and Interpretations}

The paper investigates the notion of human rights as an object of 'faith', 'religion' or 'secular religion.' While the extraordinary vagueness of all such claims and the terms contained therein makes it impossible to draw any analogy with religion in general, it remains true that several features of the theory of human rights show similarities to those of certain traditions usually called religious, most importantly Christianity.

Keywords: human rights, religion, secular religion, Christianity

Ebben az írásban nem azt a kérdést teszem fel, hogy az emberi jogok eszméje vagy egyes emberi jogok mennyiben keresztény - vagy valamivel homályosabb megfogalmazásban - „vallási” eredetűek. Ez olyan kérdés, amely szövegszerü bizonyítékok alapján eldönthető, de nem érinti a probléma lényegét: azt, hogy függetlenül az eredettől, egyáltalán lehetséges-e az emberi jogoknak olyan felfogása, amely nem ilyen (egyelőre használjuk a homályos megfogalmazást) „vallási” módon megalapozott. Másképpen szólva: nem az érdekel, hogy ténylegesen hogyan alakult ki az emberi jogok eszméje és a benne foglalt jogok katalógusa, hanem az, hogy maga az emberi jog fogalma, az emberi jogok elmélete és az elmélet érvelésmódja mennyiben tekinthető hasonlónak ahhoz, amit általában „vallásinak” szokás nevezni. Ez két különböző kérdés, és a jelen vizsgálódás kizárólag a másodikkal foglalkozik.

1 Tudományos munkatárs, NKE EJKK Politika- és Államelméleti Kutatóintézet; e-mail: nyirkos.tamas@uni-nke.hu. 
A témafelvetés egyáltalán nem meglepő vagy szokatlan. A szakirodalomból és politikai megnyilatkozásokból is jól ismert az a megközelítés, amely az emberi jogokba vetett „hitről”, az emberi jogok „vallásáról”, olykor - némileg szerényebb, de egyben ellentmondásosabb módon - „világi vallásáról” vagy legalábbis a hagyományos vallásokat „helyettesít”” voltáról értekezik. Bevezetésül tehát érdemes szemügyre venni az ilyen megnyilatkozások legjellemzőbb példáit, és megvizsgálni, milyen alapon beszélnek egyesek a vallásokkal vonható analógiáról. Ezzel kapcsolatban természetesen szükséges lesz röviden kitérni a vallás fogalmának rendkívüli homályosságára is, amelyet a forgalomban lévő definíciók egyike sem képes meggyőző módon eloszlatni. Ezután térhetünk majd vissza az emberi jogok témájára, közelebbről az emberi jogoknak nemcsak a vallási, hanem minden más átfogó megalapozását is elutasító álláspontokra, különös tekintettel arra, hogy vajon nem élnek-e ezek is olyan rejtett előfeltevésekkel, amelyek lehetetlenné teszik, hogy teljesen elszakadjunk az ilyen beszédmódtól. A konklúzió pedig egy olyan tézist fogalmaz meg, amely a vallás fogalmának elhagyásával magának az alapproblémának a pontosabb megragadását teszi lehetővé, és talán hozzájárul a kereszténység és az emberi jogok viszonyának világosabb megértéséhez is.

\section{Hit, vallás, világi vallás}

Kezdjük talán ott, hogy már az Emberi jogok egyetemes nyilatkozatának preambuluma is „az emberi jogokba vetett hitről” (faith in fundamental human rights) beszél. ${ }^{2}$ Ez persze lehetne puszta szófordulat is, ahogyan a szövegben szereplö néhány további emelkedett kitétel is: egy jobb világ „eljövetele” (advent), az ünnepélyes „kötelezettség” vagy inkább fogadalom (pledge), de idetartozik maga az „egyetemes” (universal) jelző is. Hogy nem csupán esetleges megfogalmazásokról van szó, azt az elkövetkező évtizedekben szerzők sora tette világossá: Earl Warren, az Egyesült Államok Legfelsőbb Bíróságának főbírája 1968-ban fogalmazott úgy, hogy az Emberi jogok egyetemes nyilatkozata „az emberiségbe vetett hitünk, a nem látható dolgokon alapuló hit" kifejeződése. ${ }^{3}$ Az utalás egyértelműen vallási, sőt bibliai, a Zsidókhoz írt levél 11. fejezete 1. versét idézi: „A hit a remélt dolgok biztosítéka, a nem látható dolgok bizonyítéka." De hasonlóan fogalmazott 1980-ban Vratislav Pechota, az Egyesült Nemzetek Szervezete (ENSZ) jogi bizottságának korábbi elnöke is, akinek épp az emberi jogok melletti kiállása miatt kellett emigrálnia Csehszlovákiából: „[A]z egyetemes emberi jogok kultúrája az emberi személy méltóságába és értékébe vetett hiten

2 Universal Declaration of Human Rights. Elérhető: www.ohchr.org/EN/UDHR/Documents/ UDHR_Translations/eng.pdf (A letöltés dátuma: 2020. 09. 28.) A magyar szövegben efölött könynyebb átsiklani: „[A]z Egyesült Nemzetek népei újból hitet tettek az alapvető emberi jogok [...] mellett." Emberi jogok egyetemes nyilatkozata. Elérhető: www.ohchr.org/EN/UDHR/Documents/ UDHR_Translations/hng.pdf (A letöltés dátuma: 2020. 09. 28.)

3 Earl Warren: Address. In The International Observance: World Law Day. Human Rights 1968. Genf, World Peace Through Law Center, 1969. 44-45. 45. 
alapul."4 Paul Brietzke amerikai jogtudós 1985-ben hasonlóképpen az emberi jogokba vetett „hitről” írt úgy, mint további jogok (például a „fejlődéshez való jog”) alapjáról, és a példákat hosszasan lehetne sorolni. ${ }^{5}$

Az eddigiek, mint látható, pozitív értelemben használták az emberi jogokba vetett „hit” fogalmát, de ezzel párhuzamosan kialakult egy olyan narratíva is, amelyben a hit az irracionalitás szinonimájaként, a hitre való hivatkozás pedig az elméleti megalapozatlanság bizonyítékaként jelent meg. A leghíresebb képviselője ennek a narratívának Alasdair MacIntyre, akinek Az erény nyomában című 1981-es műve szerint nemcsak arról van szó, hogy a „jogok” (köztük az emberi jogok) modern fogalmának nincsenek megfelelői a modernség előtti nyugati vagy az ettől eltérő más kultúrákban, hanem maga a fogalom is kizárólag hiten, sőt egyfajta babonás hiten alapul, és a valóságban nem felel meg neki semmi:

„A legjobb indok arra, hogy nyersen kimondjuk: ilyen jogok márpedig nincsenek, valóban pontosan olyan típusú, mint a legjobb indokunk annak kijelentésére, hogy boszorkányok vagy unikornisok márpedig nincsenek. Nevezetesen: valamenynyi arra irányuló próbálkozásunk kudarcba fulladt, hogy jó érvekkel szolgáljunk a létezésükben való hithez. [...] Az emberi jogok 1949-es ENSZ-deklarációja óta az ENSZ szokásos és szigorúan követett gyakorlatává vált, hogy az erre a deklarációra való hivatkozással egyetlen állításuk mellett se hozzanak fel érveket. E jogok legutóbbi védelmezője, Ronald Dworkin (Taking Rights Seriously, 1976) elismeri, hogy az ilyen jogok létezése nem bizonyítható, ám csak azt a megjegyzést füzi ehhez, hogy egy kijelentés bizonyíthatatlanságának tényéből még nem következik az, hogy a kijelentés nem igaz. Ez valóban így van, ám ugyanilyen jól felhasználható lenne az unikornisok és a boszorkányok létezésével kapcsolatos kijelentések mellett is."

Itt és most nem az a fontos, hogy MacIntyre mennyiben finomított a későbbiekben ezen a radikális állásponton, hanem az, hogy felhívta a figyelmet az emberi jogokba vetett hit megalapozási problémáira, miközben az elméleti és történeti érvek tudatos mellőzése - mint a későbbiekben látni fogjuk - csakugyan a mai napig jellemzi az ENSZ és más nemzetközi szervezetek gyakorlatát. Malcolm D. Evans 1997-ben egyenesen úgy fogalmazott, hogy nem is csak hitről, de „intoleráns hitről” van szó. Ha komolyan vesszük az ENSZ olyan emberi jogi dokumentumait, amelyek szerint a vallásszabadság például nem foglalja magában az olyan vallások teljes szabadságát,

4 Vratislav Pechota: East European Perceptions of the Helsinki Final Act and the Role of Citizen Initiatives. Vanderbilt Journal of Transnational Law, 13. (1980), 2. 467-500. 468.

5 Paul Brietzke: Consorting with the Chameleon, or Realizing the Right to Development. California Western International Law Journal, 15. (1985), 3. 560-601. 600. További példákért l. Robert Traer: Faith in Human Rights: Support in Religious Traditions for a Global Struggle. Washington, Georgetown University Press, 1991. 209-211.

6 Alasdair MacIntyre: Az erény nyomában. Ford. Bíróné Kaszás Éva. Budapest, Osiris, [1981] 1999. 102. 
amelyek megsértik mások emberi jogait, akkor aligha mondhatunk mást, mint hogy az emberi jogok eszméje vált olyan hitté, „amely nem kevésbé intoleráns más értékrendszerek iránt, amelyek szemben állnak saját központi elveivel, mint azok, amelyeket megszólít"?

A „hit” emlegetése ugyanakkor - akár pozitív, akár negatív értelemben - önmagában keveset mond arról, hogy milyen hitről is beszélünk. Az angol szövegek maguk is váltogatják a faith és a belief szavakat, miközben hinni valamiben nyilvánvalóan nem ugyanazt jelenti, mint egyszerủen elhinni valamit, hiszen magában foglalja a hit tárgya iránti bizalom és elköteleződés jelentésárnyalatait is. (Ahogyan ez egyébként az Emberi jogok egyetemes nyilatkozatából is kiderül.) A fó probléma azonban nem ez, hiszen hinni nyilván csak olyasmiben lehet, aminek legalább elhisszük a létezését, hanem az, hogy mindkét hit is igen sokféle lehet. Abból, hogy valaki hitet emleget, még egyáltalán nem következik, hogy hite vallási jellegü. Miért ne fogadhatnánk el, hogy az emberi jogok létezésével kapcsolatos hit egyszerủen csak hit és semmi több, annak minden - úgymond - vallási felhangja nélkül?

Nos, a legjobb okunk arra, hogy ezt ne tegyük, éppen a „vallási hit” sajátos jellege. Ha már mindenáron ragaszkodunk ahhoz, hogy a mindennapi nyelv pontatlansága miatt mindent hitnek nevezzünk, ami valamilyen meggyőződést foglal magában, akkor legalább annyit el kell ismernünk, hogy a vallási hit nagyon más, mint például az a hitem, hogy most egy számítógép előtt ülök, és ezeket a sorokat írom. Az utóbbi hitem - ahogyan Borbély Gábor megfogalmazza - azonosítható, tartós, kontextusfüggetlen, az igazságra irányul, valamilyen evidencián alapul, és nem függ attól, hogy akarom-e ezt hinni. ${ }^{8}$ A vallási hit viszont olyasmi, ami mindezzel ellentétes: sokszor ellentmondásos, időben változó, általában egy adott kontextushoz kapcsolódik, nem a világ tényleges állapotára utal, hanem arra, ahogyan a dolgoknak lenniük kellene, és egyfajta egzisztenciális döntést igényel. Az emberi jogokba vetett hit tipikusan ilyen: okairól nehezen tudunk számot adni, és nem is mindig tudjuk pontosan, mit foglal magában; bevallottan normatív természetü, és - ahogyan a deklarációk ki is mondják - döntenünk kell mellette függetlenül attól, hogy történeti vagy elméleti érvekkel alátámasztható-e.

Mindez persze kellemetlen következtetés lehet azoknak, akik egyik vagy másik oldalról szeretnék elválasztani az emberi jogokba vetett hitet - de valójában bármely filozófiai hitet - a vallási hittől. Szekuláris gondolkodók általában saját hitük lefokozásának tartják, ha a vallással kerül egy kategóriába, miközben a hagyományos vallások hívei - ha egyelőre maradunk ennél a homályos megfogalmazásnál - ugyanilyen rossz néven veszik, hogy számukra idegen elemek sorolódnak a vallási hitek közé. A legismertebb kerülő út persze az, hogy a hitek egyik formáját elválasztjuk a másiktól. Az emberi jogok esetében Cornelius Murphy már 1972-ben úgy fogalmazott, hogy „a Nyilatkozat úgy tekinthető, mint az emberi személy értékébe vetett közös

\footnotetext{
7 Malcolm D. Evans: Religious Liberty and International Law in Europe. Cambridge, Cambridge University Press, 1997. 260. 
szekuláris hit kifejeződése”. ${ }^{9}$ Hogy mitől „szekuláris”, és nem vallási ez a hit, azt persze az ilyen retorikai formulák nem szokták kifejteni, de nem szokták az olyan kritikák sem, amelyek még a hitnek ezt a szekuláris formáját is elutasítják. Michael Ignatieff például 2001-ben írta, hogy az emberi jogok eszméje „egy olyan szekuláris kultúra fő hitcikkelyévé vált, amely attól fél, hogy már nem hisz semmi másban".10

Úgy tűnik ugyanakkor, hogy már Ignatieff is lényegében felcserélhetőként használta a „szekuláris hit” és a „szekuláris vallás” kifejezéseket, hiszen fejtegetései kiindulópontja Elie Wiesel híres mondása volt, amely az Emberi jogok egyetemes nyilatkozatának 50 éves évfordulójára megjelent ünnepi kötetben az emberi jogokat nevezte a mai kor „világméretű szekuláris vallásának”. ${ }^{11}$ Ez persze burkolt elismerése annak a ténynek, hogy a „szekuláris hit” mégiscsak a vallási hitek csoportjába tartozik, vagyis semmi más nem történt, mint hogy tovább görgettük a problémát a vallási és szekuláris hitek kérdéséről az úgymond „valódi” és a szekuláris vallások kérdésére, és ez megint csak nem egyedi eset. Irwin Cotler például 2007-ben beszélt az emberi jogokról mint „korunk szekuláris vallásáról”, ${ }^{12}$ és ezt ismételte meg Anthony Julius is a Trials of the Diaspora címü könyvében 2010-ben. ${ }^{13}$

Szekuláris vallásról beszélni azonban még ellentmondásosabb, mint szekuláris hitről. Mint láttuk, szekuláris hitek elvileg létezhetnek, csupán az a kérdés, hogy ezek némelyike - esetünkben az emberi jogokba vetett hit - valóban szekuláris-e. A „szekuláris vallás” kifejezés azonban már eleve oximoron, mivel a „szekuláris” (vagy magyar megfelelője, a „világi”) - eltekintve a szó egyes történeti jelentésárnyalataitól, amelyek az időbeliségre vagy valaminek a nem egyházi, sőt nem szerzetesi voltára utalnak - általában pontosan a „vallási” ellentétét fejezi ki. ${ }^{14}$ A szekuláris vallások irodalma is így használja, és innentől kezdve voltaképpen lehetetlen eldönteni, hogy valami, amiről egyfelől elismerjük, hogy szekuláris (tehát nem vallási), hogyan lehet egyszersmind vallási is. Egy „nem vallási vallás” attól függetlenül ellentmondás, hogy az oximoron második felét, a „vallást” hogyan határozzuk meg.

A kérdés tehát nem az, hogy az emberi jogok a szekuláris vallás kategóriájába tartoznak-e, mivel ilyen kategória - az ellentmondásos retorikai nyelvhasználaton kívül - egyszerüen nem létezik. Jottányit sem változtat ezen, hogy a szekuláris vallások-

9 Cornelius Murphy: Ideological Interpretations of Human Rights. DePaul Law Review, 21. (1972), 2. 286-306. 290.

10 Michael Ignatieff: Human Rights as Politics and Idolatry. Princeton, Princeton University Press, 2001. 53.

11 Elie Wiesel: A Tribute to Human Rights. In Yael Danieli - Elsa Stamatopoulou - Clarence Dias (szerk.): The Universal Declaration of Human Rights: Fifty Years and Beyond. Amityville, Baywood, 1999. 3-4. 3.

12 Irwin Cotler: The New Anti-Semitism. In Michael Fineberg - Shimon Samuels - Mark Weitzman (szerk.): Antisemitism: The Genetic Hatred. London, Vallentine Mitchell, 2007. 15-32. 22.

13 Anthony Julius: Trials of the Diaspora: A History of Anti-Semitism in England. Oxford, Oxford University Press, 2010. 453.

14 A szótári definíciók taglalása már messze túlmenne ennek az írásnak a keretein, de a fentiekről bárki meggyőződhet, aki elolvassa az Oxford English Dictionary, a Merriam-Webster, a Macmillan vagy más értelmező szótárak idevonatkozó szócikkeit. 
nak óriási irodalma van: maga a kifejezés valamikor az 1930-as években keletkezett, és először a totalitárius rendszerek ideológiáira alkalmazták, ${ }^{15}$ de Hans Kelsen már az 1950-es években arra panaszkodott, hogy jóformán nem maradt olyan ága a modern társadalomfilozófiának, a tudománynak vagy a politikának, amelyre ne használták volna ezt a szerinte is értelmetlen fogalmat. ${ }^{16}$ (Ma pedig már olyan különös területekre is kiterjed, mint például a szelfizés gyakorlata. ${ }^{17}$ A szekuláris vallás fogalma azonban a széles körü használattól még nem lesz értelmesebb: az egyetlen tehát, amiről vitatkozni lehet, hogy indokolt-e az emberi jogok bármilyen átfogó filozófiai megalapozását a szó szoros értelmében vallásinak nevezni (minden hozzáadott jelző nélkül), vagy ez is pusztán játék a szavakkal.

\section{A vallás definíciói és az emberi jogok}

Ennek eldöntéséhez - megkockáztatva, hogy kissé elkanyarodunk az emberi jogok témájától - mindenképp szükségesnek látszik kitérni a vallás definíciójának kérdésére. Ez persze annyira ingoványos terület, hogy még a vallástudományi szakirodalom nagy része is önkényesen választ a forgalomban lévő meghatározások közül, de legalább annyit érdemes jelezni, hogy egyáltalán mi az, amiből választani lehet.

A vallásnak először is vannak „lényegi” vagy esszenciális definíciói, amelyek az öszszes, általában vallásinak nevezett jelenségben valamilyen közös pontot igyekeznek felfedezni. Ha a korábban emlegetett „hit” felől közelítjük meg a kérdést, akkor vagy az istenekbe vagy más szellemi lényekbe vetett hitet szokás megnevezni, vagy legalább valamilyen átfogó világrendbe, végső értelembe vetett hitet. Az istenekbe vetett hit nyilvánvalóan nem megfelelő, hiszen létezik olyan vallás (például a teravada buddhizmus), amely egyáltalán nem ismer istenségeket, de még azok is, amelyek ismernek, egészen más értelemben beszélnek istenekről: nehéz volna olyan meghatározást találni, amely a transzcendens keresztény Istenre ugyanúgy alkalmazható volna, mint a görög mitológia halhatatlan, de mégiscsak e világi isteneire vagy a panteizmus személytelen abszolútumára. Mint látható, a transzcendens vagy a természetfölötti kategóriája sem olyasmi, ami gond nélkül használható volna olyan kultúrákban, amelyek nem ismerik a naturalis és a supranaturalis kategóriáinak Európában is csak a középkorban kibontakozott megkülönböztetését. Az olyan kifejezések sem visznek sokkal előbbre, mint a „szellemi lényekbe vetett hit”, hiszen - hacsak nem vagyunk radikális fizikalisták - még az embertársainkba mint gondolkodó lényekbe vetett hitünk is olyasmi, ami valamilyen szellemi valóságot tulajdonít nekik. Vagyis meghatározásaink hol túl szűkek, hol túl tágak, és ha a tág meghatározásokat odáig tágítjuk, hogy

15 Emilio Gentile: Politics as Religion. Ford. George Staunton. Princeton, Princeton University Press, 2006. 2.

16 Hans Kelsen: Secular Religion: A Polemic against the Misinterpretation of Modern Social Philosophy, Science, and Politics as 'New Religions'. Bécs, Springer, 2012.

17 Mathias E. Nygaard: Selfies as Secular Religion: Transcending the Self. Journal of Religion and Society, 21. (2019). 1-21. 
mindenfajta átfogó rendbe vetett hitet vallásinak nevezünk, akkor még nehezebb lesz megmondani, miért nem vallás mondjuk a mélyökológia vagy a történelmi materializmus, illetve valójában bármely átfogó módon kifejtett filozófiai rendszer.

Ugyanígy nem jutunk túl messzire, ha a vallásokat nem hitek, hanem érzések típusaival azonosítjuk, hiszen érzés bármire vonatkozhat, és tartalmi meghatározás híján semmi alapunk nincs annak kimondására, hogy egy adott érzés „vallási” vagy „nem vallási” jellegü-e. Vagyis ismét jellemzően tág meghatározásokhoz jutunk, és ugyanez igaz a vallás olyan, funkcionális definícióira is, amelyek hol az erkölcsi összetartást, hol az egzisztenciális szorongás leküzdését, hol valami ezektől is teljesen különbözőt jelölnek meg a vallások céljaként. ${ }^{18}$ És ha ezek után - a manapság legdivatosabb módszert követve - lemondunk arról, hogy bármilyen közös lényeget fedezzünk fel a vallásokban, hanem megelégszünk azzal, hogy „klaszterfogalomként” írjuk körül őket, vagyis hosszú kritériumlisták egyikét-másikát keressük csupán bennük, akkor sem leszünk sokkal sikeresebbek. Ilyenkor ugyanis nagy valószínűséggel ismét túl tág definíciókhoz jutunk: egy morális szabályrendszer és egy ahhoz kapcsolódó rituális cselekvés például elegendő lesz ahhoz, hogy valamit vallásnak nevezzünk, míg más esetekben egy transzcendens, de pusztán filozófiai rendszer is vallásnak fog minősülni, miközben senki sem tudja megmondani, pontosan hány kritériumnak is kell teljesülnie ahhoz, hogy bármelyik vallást megkülönböztessük a nem vallásoktól. ${ }^{19}$

Mindezek alapján persze legfeljebb annyit mondhatnánk, hogy az emberi jogoknak már csak azért sincs „vallása”, mert vallások egyébként sincsenek (vagy ha vannak is, nem tudjuk, mik azok). A legtöbb szerző azonban mégiscsak elkötelezi magát valamilyen definíció mellett, ami általában a „transzcendens hit” és valamilyen „ritualizált cselekvés" kombinációját jelenti, dacára annak, hogy korábban maguk is elismerték mindkét fogalom kiküszöbölhetetlen homályosságát. Az sem sokat segít a „transzcendens” homályosságának eloszlatásában, ha olyasmivel helyettesítjük, hogy „ha lenne a világnak tökéletes fizikai leírása, akkor ennek a leírásnak a szempontjából fölösleges volna". ${ }^{20}$ Vagy helyesebben fogalmazva: az értelme tényleg világosabb, viszont egyúttal tágabb is, mint a transzcendencia metafizikailag terhelt fogalmáé. És a ritualizált cselekvés is olyasmi, ami vagy rendszerest jelent, vagy nem jelent semmit, mert ha rendszeres vallási cselekvést jelent, akkor nem lehet a vallás definíciójának része.

De még ha el is fogadjuk a tényt, hogy a szerzők többsége - vagy ami még fontosabb, számos ország vallásügyi törvényei - hasonló módon határozzák meg a vallás fogalmát, nehezen lesz eldönthető, hogy milyen alapon mondhatjuk bármilyen világnézetre vagy átfogó morális meggyőződésre, hogy márpedig nem vallási természetü. Visszatérve az emberi jogok problémájára: ha az emberi jogok eszméje valóban eszme, tehát semmi köze a világ fizikai leírásához (ami olyannyira nyilvánvaló, hogy

18 Borbély Gábor: A lehetetlen másolatai: a vallásfilozófia alapjai. Budapest, Osiris, 2018. 18-34.

19 A klaszterfogalom további - bár véleményem szerint így sem kielégítő - finomításaihoz l. Michael Stausberg - Mark Q. Gardiner: Definitions. In Michael Stausberg - Steven Engler (szerk.): The Oxford Handbook of the Study of Religion. Oxford, Oxford University Press, 2016. 9-32. 
felesleges is hangsúlyozni), ráadásul normatív eszme, tehát nem arról szól, hogy a világ milyen, hanem arról, hogy milyennek kellene lennie, akkor semmilyen értelemben nem nevezhető szekulárisnak. Ne tévesszen meg bennünket az „emberi” jelző, amelyről úgy tünik, mintha valami e világit jelentene: $a z$ ember - ebben a metafizikai általánosságban - éppolyan világfeletti eszme, mint a transzcendenciára irányuló vallások istenei.

$A z$ emberrel még senki sem találkozott, ahogyan az emberi lényeggel vagy az emberi méltósággal sem. Ami nem azt jelenti, hogy mindezek felesleges vagy értelmetlen eszmék, csupán azt, hogy nem a fizikai világ részei, nem olyan létezők, amelyeknek létezéséről a mindennapi tapasztalat vagy a tudományos kutatás biztosítana bennünket. Arról sincs szó, hogy a beléjük vetett hit irracionális volna - a hagyományosan „vallásinak” nevezett hitekről sem gondolom, hogy azok -, csupán arról, hogy ez a hit valóban hit, és nem valami más. És ha azt gondolnánk, hogy pusztán filozófiai hitről van szó, nem pedig olyasmiről, amihez úgymond „ritualizált” cselekvések kapcsolódnak, ez is könnyen cáfolható: elegendő az emberi jogi deklarációk ünnepélyes kihirdetéseire és megerősítéseire gondolni, amelyeket ráadásul egyértelmúen dogmatikus formában fogalmaz meg egy olyan intézmény (az Egyesült Nemzetek Közgyűlése), amely ebben a tekintetben egyfajta tévedhetetlen tanítóhivatalként müködik.

\section{Az ENSZ nyilatkozatai és a megalapozási kísérletek kritikája}

Jó példa erre - az Emberi jogok egyetemes nyilatkozatán túl - az ENSZ 2000-es Millenniumi nyilatkozata, amelynek 1 . pontja, bár nem az emberi jogok szúkebb témájáról beszél, hanem magáról az Egyesült Nemzetek Szervezetéről és annak Alapokmányáról, ezekkel kapcsolatban ismét az azokba vetett „hitet” (faith) erősíti meg, majd a 3. pontban az Alapokmány céljait és elveit nevezi „időtlennek és egyetemesnek. ${ }^{21}$ Ahogyan korábban máshol kifejtettem, ${ }^{22}$ a szóhasználat rendkívül figyelemre méltó: az „időtlenség” ugyanis nem egyszerűen az „örökkévalóság” szinonimája, hiszen az lehet olyan is, amely időben határtalan, nem volt kezdete és nem lesz vége. Az időtlenség viszont arra utal, hogy valami kívül van az időn, nem érvényesek rá az idő kategóriái, vagyis teljességgel transzcendens. Ha felidézzük, hogy a saecularis eredeti jelentése éppen az „időbelivel” azonosítja a „világit”, akkor még nyilvánvalóbbá válik, hogy az itt emlegetett hit (vagy egyesek szerint vallás) tárgya semmiképp sem nevezhető szekulárisnak. De az „egyetemes” jelző sem kevésbé vallási (már ha egyelöre maradunk a „vallás” szó homályos, ám sokak által használt fogalmánál).

21 United Nations Millennium Declaration. Elérhető: www.ohchr.org/EN/ProfessionalInterest/Pages/ Millennium.aspx (A letöltés dátuma: 2020. 09. 28.) A magyar fordítás ez esetben különösen érdekes: mintha az eredeti szöveg timeless kifejezését még a fordító is túlságosan erősnek érezte volna, és inkább a semleges „időtálló” kifejezéssel próbálta volna helyettesíteni. ENSZ Millenniumi Nyilatkozat. Elérhető: www.menszt.hu/hu/egyeb/millenniumi-nyilatkozat (A letöltés dátuma: 2020. 09. 28.)

22 Nyirkos Tamás: Politikai teológiák: a demokráciától az ökológiáig. Budapest, Typotex, 2018. $148-149$. 
Nem csupán azért, mert latin megfelelöjének, az universalisnak (nem is beszélve a görög katholikoszról) vannak ilyen konnotációi, hanem azért is, mert olyan egyetemességgel van dolgunk, amely - mint korábban jeleztem - nem olyasmi, ami van, hanem olyasmi, aminek lennie kell. Ha már megvalósult volna a célok és elvek egyetemessége, ha nem volnának olyanok, akik vitatják, akkor az ENSZ sem feladatokat fogalmazna meg ezekkel kapcsolatban.

Ahogyan a 2005-ös csúcstalálkozó záródokumentumának 120. pontja még határozottabban leszögezi, immár konkrétan az emberi jogok témájára vonatkoztatva: „[E]zen jogok és szabadságok egyetemes természete vitán felül áll.” ${ }^{23}$ A valóság persze az, hogy nem áll vitán felül, hiszen ha erről volna szó, akkor felesleges volna újra és újra kísérletet tenni a viták lezárására. A dokumentum 121. pontja implicit módon el is ismeri, hogy vannak ilyen viták, amikor leszögezi, hogy figyelemmel kell lenni a „nemzeti és regionális sajátosságok, illetve a különböző történelmi, kulturális és vallási háttér jelentőségére", ugyanakkor megerősíti, hogy az emberi jogok tiszteletben tartása politikai, gazdasági és kulturális rendszerektől független - tehát végső soron abszolút - kötelezettség.

A 2015-ben kiadott Fenntartható fejlődési keretrendszer (Agenda 2030) ennek megfelelően már nem is utal az emberi jogok egyetemességével kapcsolatos nézetkülönbségekre, miközben a szövegben tizennégyszer fordul elő az „emberi jogok” kifejezés. Ehelyett a korábbi dokumentumokat, az Alapokmányt, az Emberi jogok egyetemes nyilatkozatát, a Millenniumi nyilatkozatot és a 2005-ös csúcstalálkozó záródokumentumát tekinti kiindulási pontnak, ha úgy tetszik, olyan dogmatikai alapnak, amelyre a jövőben építkezni kell. ${ }^{24}$

A megalapozási kísérletekhez való viszony tehát némileg paradox abból a szempontból, hogy miközben a hivatalos dokumentumok abszolút és megkérdőjelezhetetlen elveket fogalmaznak meg, egyben el is utasítanak minden olyan törekvést, amely bármilyen abszolút és megkérdőjelezhetetlen filozófiai vagy vallási alapra helyezné ezeket. Az emberi jogok „vallása”, mint láttuk, egyes politikusok és elméleti szerzők szóhasználata - maga az ENSZ sohasem nyilvánított ki ilyesmit, eltekintve a „hitre” (de sohasem vallási hitre) vonatkozó homályos utalásoktól. Ennek fó oka természetesen az, hogy a „vallás” - helyesebben a „vallások” - ma gyüjtőnév, és semmilyen vallásra nem lehet úgy hivatkozni, hogy egy másik vallás nevében ne lehetne vitatni annak univerzalitását. Az emberi jogok eszméjére leselkedő legnagyobb veszély pedig mindig is az volt, hogy akár eredete, akár a benne foglalt jogok listája partikulárisnak bizonyul, és éppen ez az, amit az ENSZ deklarációi mindenképpen ki akarnak zárni. Ahogy Jacques Maritain már az Emberi jogok egyetemes nyilatkozatának

23 Resolution adopted by the General Assembly on 16 September 2005. Elérhető: https://undocs.org/ en/A/RES/60/1 (A letöltés dátuma: 2020. 09. 28.)

24 Transforming our world: The 2030 Agenda for Sustainable Development. Elérhető: https://sustainabledevelopment.un.org/post2015/transformingourworld (A letöltés dátuma: 2020. 09. 28.) 
megszövegezésekor megfogalmazta: „[E]gyetértünk a jogokban, de csak azzal a feltétellel, hogy senki sem kérdezi meg tőlünk, miért.”25

Maritain persze arra gondolt, hogy vannak olyan intuitív meggyőződéseink az emberi személy méltóságáról, az emberi szabadságról és az ezzel kapcsolatos jogokról, amelyek minden nagy kultúrában jelen vannak, vagyis nem szükséges konkrétan utalnunk ezek alapjaira egyik vagy másik hagyományban. Vannak azonban olyan elméleti szerzők is - sőt jelenleg ők vannak többségben -, akik szerint egyáltalán nem szükséges ilyen megalapozásra törekedni. Ahogyan a korábban idézett Ignatieff kifejtette, az emberi jogok melletti érvelésnek helyesebb volna azzal foglalkoznia, hogy mit tesznek ezek a jogok az emberekért, és nem azzal, hogy mit is jelentenek az olyan homályos és vitatható kifejezések, mint az „emberi méltóság” vagy az „emberi természet”, amelyek legalább annyira terheltek metafizikailag, mint bármely „vallási” fogalom. ${ }^{26}$

A kérdés csupán az, hogy valóban megkerülhetö-e ilyen módon az Ignatieff által hol metafizikainak, hol vallásinak nevezett megalapozás problémája. Ö maga a grounding, base és hasonló kifejezéseket részesíti előnyben a foundation-nel szemben, de ezzel legfeljebb a megalapozás egy másik formáját tudjuk definiálni:

„Érvelésem szerint az a fajta megalapozás (grounding), amelyre a modern emberi jogoknak szükségük van, azon alapul (based on), amit a történelem tanít nekünk: hogy az emberek élete veszélybe kerül, ha nem rendelkeznek a szabad cselekvőképesség egy minimális fokával; hogy maga a cselekvőképesség nemzetközileg elfogadott szabályok védelmét igényli; hogy ezen szabályoknak felhatalmazást kell nyújtaniuk számukra, hogy szembeszálljanak saját államaik igazságtalan törvényeivel és rendelkezéseivel; és végül, ha már minden más lehetőséget kimerítettek, az egyéneknek joguk legyen más népekhez, nemzetekhez és nemzetközi szervezetekhez fordulniuk segítségért, hogy megvédjék jogaikat."27

Ha alaposabban megvizsgáljuk a szöveget, az is kiderül, hogy a megalapozás még csak nem is más típusú, mint amit korábban metafizikainak vagy vallásinak neveztünk. Attól, hogy a kiinduló premissza - az egyén élete mindenek felett álló érték, amelyből minden más következik - nincs nyíltan kimondva, még nagyon is filozófiai tétel marad. A történelmi tapasztalatra való hivatkozás is csak annyiban helytálló, amenynyiben elfogadjuk ezt az alapvető kijelentést, és nem érvelünk például amellett, hogy egy nagyobb jó - például a közösség java - érdekében az egyén élete akár fel is áldozható. A legtöbben ma elutasítanánk egy ilyen érvelést, de hogy pontosan milyen alapon, az nehezen mondható meg, ha eltekintünk az emberi személy inherens értékének koncepciójától. Ám ezzel még csak egyetlen alapvető jogot, az élethez való jogot

25 Human rights: Comments and Interpretations. With an Introduction by Jacques Maritain. Paris, UNESCO/PHS/3 (rev.), 1948. Elérhető: http://unesdoc.unesco.org/images/0015/001550/155042eb. pdf (A letöltés dátuma: 2020. 09. 28.)

27 Uo. 55. 
említettük, és az, hogy ez hogyan terjeszthető ki minden más olyan jogra, amelyet az ember "cselekvőképessége" feltételez, vagyis miért és mikor szállhatunk szembe az általánosabb értelemben vett „igazságtalan törvényekkel”, ismét csak filozófiai indoklást feltételez. Természetjogi felfogásban persze érvelhetünk úgy, hogy az igazságosságnak van valamilyen objektív mércéje, amely nem merül ki az egyéni élet védelmében, de a szerző itt éppen az ilyen érvelésektől kívánt eltekinteni. Az pedig, hogy a nemzetközi szervezetek általában eredményesebben képviselik a jogok védelmét, mint az egyes államok, szintén olyasmi, ami történetileg vagy igazolható, vagy nem, de általános tételként kimondva már bizonyosan túlmegy az empirikus tényeken.

Az természetesen igaz, hogy egy „prudenciális” és „történeti” érvelés nagyobb teret engedne a különböző kultúrák erkölcsi pluralizmusának, mint egy olyan, amely tisztán elméleti és dogmatikus. A kérdés csupán az, hogy az egyetlen alapvető emberi jogból - az élethez való jogból - levezetett jogok komplex rendszere miért ne lenne maga is elméleti és dogmatikus: miért mondhatja Ignatieff azt, hogy az egyének persze „nem élvezhetnek korlátlan jogokat annak meghatározásában, hogy mi számít jogsértésnek", ha nincs egy olyan objektív mérce, amely emberi akaratoktól és érzésektől függetlenül definiálja ezeket.

De ezzel talán már túl is mentünk azon, amit a megalapozásról és annak kritikájáról mondani érdemes. Az emberi élet, az emberi személy értéke, az egyén jogai semmivel sem lesznek kevésbé metafizikai alapfogalmak attól, hogy nem - vagy nem rögtön - építünk rájuk egy kifejlett dogmatikát. Ha valakinek nem tetszik a „vallás” szó, használhatja az „ideológiát” is, sőt azt is mondhatja, hogy „keskeny központú”, tehát nem az élet minden területét felölelő ideológiáról van szó. ${ }^{28}$ Ekkor is el kell ismernie azonban, hogy az ilyen ideológiák azt helyettesítik, amit általában - bármilyen homályos gyűjtőnévvel - „vallásnak” szokás nevezni, mint tette azt Torkel Opsahl, az Emberi Jogok Európai Bizottságának korábbi tagja, vagy Louis-Edmond Pettiti, az Emberi Jogok Európai Bíróságának bírája. ${ }^{29}$ Helyettesíteni valamit valamivel persze csak akkor lehet, ha a két dolog legalább fó vonásaiban vagy funkcióiban megegyezik, vagyis a szóhasználattól függetlenül megint csak odajutottunk, hogy az emberi jogok ideológiája - a szót itt semleges értelemben használom, mint elvek és értékek társadalmi értelemben is releváns rendszerét - rendkívül nehezen különíthető el az úgymond „vallásos” ideológiáktól.

Ha minden hasonló szót kerülni akarunk, akkor nem marad más, mint az emberi jogok egyfajta pozitivista felfogása: emberi jog mindaz, amit jogi szövegek akként definiálnak. Ez kétségkívül elkerüli a megalapozás minden buktatóját: a gond csak az, hogy az emberi jogok tipikusan metajurisztikus normák, amelyekre jellemző módon akkor hivatkozunk, amikor egy adott állam törvényei vagy gyakorlata nem állnak

28 A thin-centered ideology kifejezés Cas Mudde populizmusról szóló írásaiban fordul elő leggyakrabban, de Ignatieff is „keskeny elméletnek” nevezi saját emberi jogi felfogását. Uo. 56. Vö. Cas Mudde - Cristóbal Rovira Kaltwasser: Populism: A Very Short Introduction. Oxford, Oxford University Press, 2017. 6.

29 L. Traer i. m. (5. lj.) 210. 
összhangban ezekkel, vagy amikor iránymutatásokat akarunk adni a tételes törvények megalkotásához. Az emberi jogok - és ebben azért konszenzus van - nem akkor keletkeztek, amikor az Emberi és polgári jogok nyilatkozata vagy az Emberi jogok egyetemes nyilatkozata kihirdette őket, hanem már mindig is velünk voltak függetlenül attól, hogy valamilyen jogi szöveg elismerte-e őket, vagy sem.

Hadd hangsúlyozzam még egyszer: a megalapozással kapcsolatos nehézségek nem azt jelentik, hogy az emberi jogok ideája (vagy akár ideológiája) felesleges vagy értelmetlen. Az eszmék, eszmerendszerek, világnézetek mindegyikére igaz, hogy nem tudományos alapokon nyugszanak, hanem értékek és elvek elfogadásán. Ha ezek az értékek és elvek ráadásul abszolút érvényre tartanak számot, még közelebb kerülünk ahhoz, amit manapság sokan „vallásnak” neveznek. A magam részéről azonban sohasem állítottam, és továbbra sem állítok olyasmit, hogy minden ideológiai vagy világnézeti rendszert - beleértve az emberi jogokét is - vallásnak kellene nevezni. A vallás fogalmát, mint látható volt, olyannyira parttalannak érzem, hogy legszívesebben semmit sem neveznék annak, és ezért zárásul sem azt a kérdést vizsgálom, vajon van-e olyasmi, mint az emberi jogok vallása, hanem azt, hogy az emberi jogok fogalma és elmélete sajátos értelemben mely - olykor vallásinak nevezett - hagyományokkal áll a legközelebbi rokonságban.

\section{Az emberi jogok párhuzamai}

Ahogyan az eddigiekből kiderült, az emberi jogok fogalma mindenképpen valamilyen abszolútumot feltételez. Ez az abszolútum lehet maga az emberi jogok eszméje, vagy valami olyan, amire az emberi jogok visszavezethetők: az emberi méltóság, az emberi személy inherens értéke vagy az egyéni szabadság. Ezek annyiban abszolútumok, hogy tovább már nem elemezhetők, róluk vitának helye nincs, és minden más állítást ezek alapoznak meg.

Eleve kérdéses, hogy minden, úgynevezett vallási hagyomány rendelkezik-e ilyen kiforrott abszolútumfogalommal, de a különbség még látványosabb, ha arra gondolunk, hogy ez az abszolútum teljességgel transzcendens abban az értelemben, hogy tapasztalatfeletti, nem olyasmi, aminek létezéséről bármilyen formában meggyőződhetnénk ebben a világban. Az olyan „vallások” tehát, amelyek még istenségeiket is természeti létezőkként gondolják el, nyilvánvalóan kiesnek a lehetséges párhuzamok közül: az úgymond „természeti vallásokat” épp azon az alapon nevezzük így, hogy fizikai jelenségeket személyesítenek meg vagy ruháznak fel rendkívüli jelentőséggel. ${ }^{30}$ Egy transzcendens abszolútum ugyanakkor - nem szükségképpen, de általában - univerzális is, tehát az olyan törzsi vagy nemzeti „vallások”, amelyek csak saját közösségük

30 Ahogyan Molnár Tamás írja, az archaikus szemlélet számára a szentség nem valamiféle transzcendens hit, hanem közvetlen tapasztalat tárgya volt. „Kétségtelen jellege két forrásból fakadt. Egyrészt abból, ahogyan az ember a környező természetet, másrészt saját és mások lelki indítékait naponként megtapasztalja." Molnár Tamás: A hatalom két arca: politikum és szentség. Ford. Mezei Balázs. Budapest, Európa, [1988] 1992. 84. 
isteneit vagy szellemeit tisztelik, úffent egészen más kategóriába tartoznak. (Ne feledjük, hogy ez még a korai zsidóság istenképére is jellemző volt: a „ne legyen más Istened" parancsa nem zárja ki, hogy léteznek más istenek, csupán ezek imádását tiltja a közösség számára.)

Az emberi jogok emellett nem pusztán abszolút, transzcendens és egyetemes értékek, hanem morális értékek is, és közismert, hogy például a görög vagy a római mitológiától igen távol állt erkölcsi parancsok megfogalmazása. Nem véletlen, hogy az antik filozófusok többsége inkább egyfajta filozófiai istentanból (természetes teológiából) próbált etikát levezetni, ahogyan az államok is megkülönböztették a polgári erényeket megalapozó politikai teológiát a mitikus teológiától. Az emberi jogok morális értékrendszere ráadásul - mint láttuk - mindig az egyént helyezi a középpontba, tehát ellentétben áll az olyan, immár sokadszor idézőjelbe tett „vallási” rendszerekkel is, ahol az egyéni bünnél és erénynél alapvetőbb az egész közösség bűne és erénye, ahogyan ezt még a kései zsidóság esetében is látjuk (de voltaképpen idesorolható a magyar Himnusz „megbünhődte már e nép a múltat s jövendőt” kitétele is).

$\mathrm{Az}$ abszolút, transzcendens, univerzális, morális parancsokat megfogalmazó és az egyén jelentőségét hangsúlyozó emberi jogi eszmerendszer egyben feltételezi azt is, hogy valóban rendszerről beszélünk, tehát emberi ésszel felfogható, szabatosan kifejthető és tételesen leírható dogmákról, ahol a „dogma” szót megint csak semleges értelemben használom annak minden negatív felhangja nélkül. A végső igazság megismerhetetlenségét hirdető indiai hagyományokkal vagy a tételes hitvallásokat általában nélkülöző „vallásokkal” tehát megint csak kevés párhuzam látszik, és ne feledjük, hogy a kereszténységen kívül szinte minden más hagyomány idetartozik.

Ezek után már semmi meglepő nincs abban, hogy az emberi jogok vagy tágabb keretük, az ENSZ Alapokmányának elvei nemcsak exkluzívak a rivális eszmékkel szemben, de az előbbieket egy olyan, üdvtörténeti keretbe ágyazzák, amely a szenvedésnek tulajdonít az emberiséget megváltó erőt. Ez talán kevésbé nyilvánvaló a dokumentumok felületes olvasói számára, de a finn Mika Luoma-aho 2012-ben meggyőzően érvelt amellett, hogy amikor az Alapokmány a két világháború borzalmait és a hasonlók jövőbeni elkerülését nevezte meg az ENSZ létrehozásának legfőbb indokaként, akkor voltaképpen nem tett mást, mint értelemmel ruházott fel egy sokak számára értelmetlennek tűnő tényt, több tízmillió ember halálát. „A világháborúk halottait a vezetők nem értelmetlen emberveszteségként könyvelték el. Ehelyett úgy írtak a veszteségről, mint egy új kezdetről: olyan értelmes áldozattá formálva, amely kötelezi - nem: köteleznie kell - a későbbi generációkat az egymás iránti felelősségre."31

Az értelemadás gesztusa és az emberiség jövőjébe vetett hit pedig ismét csak nem a „vallások” közös sajátossága, hiszen ezek nagy része inkább a ciklikusság - sőt a ciklusokon belüli hanyatlás - gondolatából indul ki. De még a körkörös idő elképzelését elutasító olyan hagyományokból is hiányzik a szenvedés és a halál megváltó erejébe

31 Mika Luoma-aho: God and International Relations: Christian Theology and World Politics. New York, Continuum, 2012. 104. 
vetett hit, mint például az iszlám, amely Jézus kereszthalálát is ezen az alapon vonja kétségbe. ${ }^{32}$

A világ összes, általában „vallásinak” nevezett tradícióját persze lehetetlen sorra venni, de talán ennyiből is látszik, hogy az emberi jogok vallásáról nem csupán azért félrevezető beszélni, mert maga a „vallás” szó jelentése zavaros, hanem azért is, mert a nagyvonalúan idesorolt jelenségek többségére a legkevésbé sem hasonlít. Ha egyáltalán vannak párhuzamai, akkor még leginkább a kereszténységben találunk ilyeneket: egy olyan, transzcendens abszolútumban való hitet, amely univerzális erkölcsi parancsokat fogalmaz meg, tiszteli az emberi személyt, jelentést tulajdonít a történelemnek, s habár igyekszik az emberi szenvedést csökkenteni, nem tagadja le a szenvedésnek az emberi értelmet zavarba ejtő valóságát sem.

Ebből persze önmagában nem következik, hogy az emberi jogok eszméje keresztény eszme. Az eredet kérdéséről csak eszmetörténeti vizsgálódások mondhatnak valamit, nem strukturális analógiák. Ráadásul ez utóbbiak sem tökéletesek, hiszen az emberi jogok nem feltételeznek személyes Istent, és a velük kapcsolatos remény is radikálisan e világi, még ha magát az eszmét a nyilatkozatok olykor „időtlennek” nevezik is. A legtöbb, amit mondhatunk, hogy az emberi jogokról való gondolkodás egyes vonásaiban nagyon hasonlít a keresztény gondolkodásra, miközben másokban elszakad attól. Hogy pontosan melyek ezek a vonások, azt már a keresztényeknek kell eldönteniük, akik azonban sohasem felejthetik el, hogy ebben a világban semmi, még a legrokonszenvesebb eszme sem foglalhatja el magának az Istennek a helyét.

\section{Irodalomjegyzék}

Borbély Gábor: A lehetetlen másolatai: a vallásfilozófia alapjai. Budapest, Osiris, 2018.

Brietzke, Paul: Consorting with the Chameleon, or Realizing the Right to Development. California Western International Law Journal, 15. (1985), 3. 560-601.

Cotler, Irwin: The New Anti-Semitism. In Fineberg, Michael - Samuels, Shimon - Weitzman, Mark (szerk.): Antisemitism: The Genetic Hatred. London, Vallentine Mitchell, 2007. 15-32.

Emberi jogok egyetemes nyilatkozata. Elérhető: www.ohchr.org/EN/UDHR/Documents/UDHR_ Translations/hng.pdf (A letöltés dátuma: 2020. 09. 28.)

ENSZ Millenniumi Nyilatkozat. Elérhető: www.menszt.hu/hu/egyeb/millenniumi-nyilatkozat (A letöltés dátuma: 2020. 09. 28.)

Evans, Malcolm D.: Religious Liberty and International Law in Europe. Cambridge, Cambridge University Press, 1997. DOI: https://doi.org/10.1017/CBO9780511599378

Gentile, Emilio: Politics as religion. Ford. Staunton, George. Princeton, Princeton University Press, 2006.

Human Rights: Comments and Interpretations. With an Introduction by Jacques Maritain. Paris, UNESCO/PHS/3 (rev.), 1948. Elérhető: http://unesdoc.unesco.org/images/0015/001550 /155042eb.pdf (A letöltés dátuma: 2020. 09. 28.)

Ignatieff, Michael: Human Rights as Politics and Idolatry. Princeton, Princeton University Press, 2001. DOI: https://doi.org/10.1515/9781400842841

32 Korán 4:157-158. 
Julius, Anthony: Trials of the Diaspora: A History of Anti-Semitism in England. Oxford, Oxford University Press, 2010.

Kelsen, Hans: Secular Religion: A Polemic against the Misinterpretation of Modern Social Philosophy, Science, and Politics as "New Religions". Bécs, Springer, 2012.

Luoma-aho, Mika: God and International Relations: Christian Theology and World Politics. New York, Continuum, 2012.

MacIntyre, Alasdair: Az erény nyomában. Ford. Bíróné Kaszás Éva. Budapest, Osiris, [1981] 1999.

Molnár Tamás: A hatalom két arca: politikum és szentség. Ford. Mezei Balázs. Budapest, Európa, [1988] 1992.

Mudde, Cas - Rovira Kaltwasser, Cristóbal: Populism: A Very Short Introduction. Oxford, Oxford University Press, 2017. DOI: https://doi.org/10.1093/actrade/9780190234874.001.0001

Murphy, Cornelius: Ideological Interpretations of Human Rights. DePaul Law Review, 21. (1972), 2. 286-306.

Nygaard, Mathias E.: Selfies as Secular Religion: Transcending the Self. Journal of Religion and Society, 21. (2019), 1-21.

Nyirkos Tamás: Politikai teológiák: a demokráciától az ökológiáig. Budapest, Typotex, 2018.

Pechota, Vratislav: East European Perceptions of the Helsinki Final Act and the Role of Citizen Initiatives. Vanderbilt Journal of Transnational Law, 13. (1980), 2. 467-500.

Resolution Adopted by the General Assembly on 16 September 2005. Elérhető: https://undocs.org/ en/A/RES/60/1 (A letöltés dátuma: 2020. 09. 28.)

Stausberg, Michael - Gardiner, Mark Q.: Definitions. In Stausberg, Michael - Engler, Steven (szerk.): The Oxford Handbook of the Study of Religion. Oxford, Oxford University Press, 2016. 9-32. DOI: https://doi.org/10.1093/oxfordhb/9780198729570.001.0001

Traer, Robert: Faith in Human Rights: Support in Religious Traditions for a Global Struggle. Washington, Georgetown University Press, 1991.

Transforming Our World: the 2030 Agenda for Sustainable Development. Elérhető: https://sustainabledevelopment.un.org/post2015/transformingourworld (A letöltés dátuma: 2020. 09. 28.)

United Nations Millennium Declaration. Elérhető: www.ohchr.org/EN/ProfessionalInterest/Pages/ Millennium.aspx (A letöltés dátuma: 2020. 09. 28.)

Universal Declaration of Human Rights. Elérhető: www.ohchr.org/EN/UDHR/Documents/UDHR_ Translations/eng.pdf (A letöltés dátuma: 2020. 09. 28.)

Warren, Earl: Address. In The International Observance: World Law Day. Human Rights 1968. Genf, World Peace Through Law Center, 1969. 44-45.

Wiesel, Elie: A Tribute to Human Rights. In Danieli, Yael - Stamatopoulou, Elsa - Dias, Clarence (szerk.): The Universal Declaration of Human Rights: Fifty Years and Beyond. Amityville, Baywood, 1999. 